\title{
Grave Judicial Errors Within the Jordanian Legal System: Causes, Legal Provisions and Solutions
}

\author{
Alaa Mohammad Alfawaer ${ }^{1}$ \\ ${ }^{1}$ Faculty of Law, University of Jerash, Jordan \\ Correspondence: Alaa Mohammad Alfawaer, Faculty of Law, University of Jerash, Jordan. E-mail: \\ suhelftlaui@yahoo.com
}

Received: October 25, 2016

Accepted: November 11, 2016

Online Published: February 28, 2017

doi:10.5539/jpl.v10n2p122

URL: https://doi.org/10.5539/jpl.v10n2p122

\begin{abstract}
It is reasonably and logically conceivable that a judge commits a grave judicial error during the undertaking of his or her judicial work, whether related to legal principles, in the performance of his or her judicial duties or in his exercising of jurisdiction. This error is related to his or her civic responsibility, if it has resulted in damages to a member of the opposing party. Despite the importance and seriousness of such mistakes, and its long establishment, Jordanian legislation has not provided for it, and has left it to the general rules. There is no doubt that there are reasons which lead to such errors occurring and, conversely, that there are ways to avoid this error.
\end{abstract}

Keywords: judicial, errors, applications, principles, applications

\section{Introduction}

\subsection{Topic of Study}

This study deals with the subject of grave judicial errors. As we know, a judge is not infallible or incapable of error. Consequently, while undertaking his or her judicial work, he or she may commit a grave judicial error, a reflection of his or her legal ignorance in a certain area or an inconceivable neglect of his or her duties, which leads to the infliction of harm upon one of the litigants. This opens him or her up to legal action against him or her, and to claims for compensation. This is according to the general rules, given the fact that Jordanian law does not stipulate for cases of grave judicial errors in particular and in general, unlike in France, Egypt, Lebanon and other countries. This study aims to shed light on this subject from all angles.

\subsection{The Significance of the Study}

The grave judicial error is a subject of great importance for judges, lawyers and the assembly of litigants. Despite the importance of this issue, the Jordanian legislator has left it to general rules. The topic is not covered in particular, individually or independently by 'Fiqh' Islamic jurisprudence and religious commentary in the Kingdom of Jordan. Many judges are still made immune from such errors, and do not take responsibility for them.

\subsection{Aims of the Study}

This study aims to address the topic of serious errors from all angles, including explaining the concept and its genesis, its forms and applications, the reasons for its occurrence, and providing solutions to prevent or limit its occurrence, and to make suggestions to the legislator on the appropriate manner to deal with this subject. Finally, the paper will clarify when a judge has committed grave mistake and when he or she has not.

\subsection{The Issue}

When should a Jordanian judge take responsibility for a grave judicial error?

\subsection{Questions Around the Issue}

What is a grave error? What are the forms and applications of the term? What are the reasons for its occurrence? How can we limit its occurrence?

\subsection{Methodology of the Study}

This study is based on an analytical methodology, whereby analysis is undertaken of texts, jurisprudential opinions and judicial decisions relating to it. 


\subsection{Plan for the Study}

This study comprises two sections. The first section focuses on what constitutes a serious judicial error and discusses three issues: first, the emergence of the error, and the second the concept, and the third its forms. The second section is entitled 'applications', and the reasons and ways to avoid grave judicial error. A section has been allocated for each issue, including the epilogue which includes findings and recommendations.

\section{The Definition of Grave Judicial Errors}

The significance of a serious judicial error can be highlighted by looking at the genesis of this error, by shedding light on this concept and by explaining its forms. Knowledge of these matters will constitute a full understanding of the essential nature of the judicial error. Consequently, we will deal with each of these items as a separate 'issue' in this section, and in the following manner:

Issue One: The Origins of the Grave Judicial Error

Issue Two: The Definition of the Grave Judicial Error

Issue Three: The Forms of the Grave Judicial Error

\subsection{The Origins of the Grave Judicial Error}

The grave judicial error is characterized by its age, and its birth or establishment were not modern events, as it has been known for hundreds of years. It made its first appearance in France, where the Civil Code issued in 1540, during the reign of French King Francois the first, stipulated on the matter. This law stipulated the consideration of a gross judicial error committed by a judge during his judicial work as reason for his litigation. Then grave judicial error disappeared from the French civil law which was issued in 1579, on the grounds that judicial corruption did not require it. Due to criticism of the law of 1759 which did not stipulate for the matter of the grave judicial error, and because corruption differs from gross judicial errors, and because of the grave dangers frequently befalling judges, the French legislator was forced to stipulate again on the matter of the grave judicial error during the fourth year of the French revolution. However, this did not last long, as it was soon removed by the French legislature in 1806. In this period, and subsequent periods extending to before 1933, the French courts confirmed their ruling that an error committed by a judge is a serious miscarriage of justice, and that it is not possible for him or her to be sentenced to pay compensation, because compensation is not stipulated in this case, but rather for cheating and corruption only. In the face of these court rulings, and the abolition by the French legislator of the grave judicial error, and the lack of compensation for it, French jurisprudence began to criticize this matter. French jurisprudence justified the need to restore the stipulation for the grave judicial error and to compel the judge to compensate the aggrieved for his or her grave mistake in what follows:

A. Any judge who sits on the bench should not be ignorant of the basic principles of law, and should not neglect or fail in the performance of his or her major duties.

B. Those who are harmed by the grave judicial error have the right to seek compensation from the judge.

C. The judge who has perpetrated a grave judicial error has the status of a reckless driver on the road who causes accidents because of his or her own carelessness and recklessness.

Following objections and criticisms, and the high frequency of demands for a return to the stipulation of grave judicial errors, the French legislator was forced to reinstate it. This was achieved in a law issued in 1933, and not only this, but it was also provided for, in addition to in the civil law, in other laws such as the Civil Procedure Law (Civil Procedure), the Law of the Just Organization of the Judiciary. This law allowed individuals to claim compensation from the state, but not from the judiciary, and is still in place today (Faouri, 2015:25 onwards).

As for the situation in Egypt, despite the acknowledgement and provision for corruption, trickery, treachery and the denial of justice by the Egyptian legislature as reasons for the litigation of judges in the Procedural Law of 1875, and the Law of Civil Procedures in the year 1883, it did not provide among these for grave judicial errors as a reason for the litigation of civil judges. But this error was addressed in a meeting alongside the preparation of the draft Procedural Code of 1949, when one side of the members of the committee to prepare the procedural code demanded the provision for grave judicial errors within the code. They did so because they understood that grave judicial errors run parallel to corruption, and because they believed that a judge could be seriously negligent in the undertaking of certain legal procedures, which could result in serious damage. They argued that if there was provision made for grave errors, it would not need to be a source of fear for judges, as there would be guarantees protecting them.

As for the other side of the committee for the preparation of a draft Procedural Code, they strongly objected to the provision for grave judicial errors in the draft Procedural Code as it could be understood loosely, broadly, 
flexibly and in an uncontrollable way. They argued that it could be widened or narrowed according to its application and understanding, and there could be conflicting views on its interpretation, and upon when it had occurred or not occurred. In many cases, they suggested, some people may consider it to be a grave judicial error and others may not. The committee to prepare a draft Procedural Code for the year 1949 concluded that grave judicial errors should be provided for, and the Egyptian Procedures Act of 1949 is considered the date of the birth of the concept of the gross judicial error in Egypt. This law continued to provide for it even when Procedures Act No. 13 of 1968 was released until Article 494 stipulated for such errors. ${ }^{1}$

In Lebanon, the legislator did not provide for this judicial error until 1961 when it issued the Judicial Organization Law No. 8755 of 1961, in which the legislature has not only provided this error, but indeed cited the definition that: "A violating mistake will not take place, provided that the judge shows the normal degree of attention to his or her duties, as stipulated by the Lebanese legislation on this error in the Civil Procedure Act No. 90 of 1983, specifically in Article 741 thereof" (Faouri, 2015:47).

As for the Hashemite Kingdom of Jordan, in both civil law ${ }^{2}$ and the Code of Civil Procedure ${ }^{3}$ any stipulation of grave judicial errors is absent. The same is the case in the law of the independence of the judiciary ${ }^{4}$, because the legislature has not provided for the litigation of civilian judges, which does not mean that it has given them refuge from it or made them immune to it, but rather it leaves all matters and issues relating to the litigation of judges to the general rules in the Civil Code and the Code of Civil Procedure (Faouri, 2015:52).

Thus, we see clearly from the above, that grave judicial error is not a recently emerging idea, but a very old idea rooted in hundreds of years of history in France, and yet the Jordanian legislative system continues to lack any stipulation on this matter with no logical justification, rationalization, or practical reality.

So, it would be much better if the Jordanian legislator stipulated on the matter in the Civil Code, in the Code of Civil Procedure, and the law of the independence of the judiciary, because if the truth be told there is an urgent need to provide for it. We will explain this necessity. We have addressed the matters of the concept of this error, its forms and the applications of this research.

\subsection{The Definition of a Grave Judicial Error}

'Grave judicial error' is regarded as a general, wide-ranging, loose, flexible, variable and saturated concept, and it is our belief that it is closely related to ideas about: public order, public morals, customs and habits. What is considered the custom or habit, or public order or public morals, in a certain time and place in a certain country may not be the case in another time and place and another country.

The grave judicial error is also like this: for an error can take place in a certain place and time in a country, and meanwhile an error can take place in a different place and time in another country, and the first mistake takes the character and status of the concept of gross judicial error, whereas the second mistake does not espouse this description and character.

We agree with another when he said that there is nothing more "fluid" and "stretchy" than the concept of a serious judicial error (Al-Khoury, 2002:44). The grave judicial error was not recognized by the French legislature, and the legislator of the Judicial Justice Organization Law was satisfied with stipulating that the state asks about the activity of the Judicial Justice Facility in the case of a grave judicial error and in the case of denial of justice, and the French jurist Andre Henry recognized that this error "is that which is not committed by a judge

\footnotetext{
${ }^{1}$ On the origins of gross miscarriage of justice in Egypt, see:

Muhammad 'Eid al-Qasaas, The Mediator in Civil, Commercial and Administrative Procedural Code, Arab Renaissance Publishing House (Dar al-Nahdha al-Arabia), Cairo, 2005, p88 onwards.

Abd Hamid Minshawi, Commentary on Procedural Law in Civil and Commercial Administrative Materials, University Publications House (Dar al-Matbu'at al-jama'ia), Alexandria, 2008, p709 onwards.

Ahmed al-Said Sawi, The Mediator in Civil and Commercial Procedural Law,

Cairo University Press, Cairo, 1990, p121 onwards.

Ahmed Hindi, The Origins of Procedural Code, Manshat al-Ma'arif, Alexandria, 2002, p506 onwards.

Muhammed al-Said Rushdi, An Error is Inexcusable, Kuwait University Press, Kuwait, 1995, p154 onwards

Ahmed Meligi, The Comprehensive Encyclopedia for Commentary on Procedural Code, Volume VI, The Technical Office of Legal Publications, place and date of publication unknown, p1991 onwards,

Hassan Ali Alznon, Civil Liability, Part One, Damages, Dar Wael, Amman, 2005, p595.

${ }^{2}$ Civil Law No. 43 of 1976.

${ }^{3}$ Civil Procedure Act No. 24 of 2014.

${ }^{4}$ Independence of the Judiciary Act No. 29 of 2014.
} 
with a usual level of concern for his or her duties, and who strives to do his or her work as a conventional person does, provided that the court sets the benchmark against which to differentiate between the small mistake that requires a reprimand from the authorities and between serious mistake which requires civil liability through the raising of a lawsuit."

The French Court of Appeal recognized this error as: that which is not committed by an attentive judge, but rather that which is perpetrated because of a grievous error, which can be perpetrated only by a judge who has neglected his or her work and does not undertake it with the required attitude, and this error is indicated in the abnormal behavior of the judge, and indeed is behavior which contradicts the very reason for the existence of the judiciary (Abu Yazbek, 2009:17-18).

It can be noted in the jurisprudential definition referred to above, that the grave juridical error is given a personal character, that is it is equated to the person of the judge. As for the judicial definition, it is endowed with an objective character that is its association and link to the judicial establishment. The reason for this is that a serious error of justice in France has become regarded as a systematic error and not a personal mistake of the judge.

In Lebanon, the Lebanese legislator has defined a grave judicial error as: "a serious mistake which would not befall a judge concerned with his or her ordinary duties."

There is no doubt that this definition has allotted a personal element to this error and considered it to be professional misconduct, and limited it to the behavior of the judge during his or her judicial work. As for the Lebanese judiciary, the Court of Cassation Authority considered serious judicial error to be: "Excessive negligence matched by ignorance of the law, and it is a flagrant mistake arising from negligence and malice, and it is an error which does not befall judge who cares about his or her duties to a normal degree" (Saab, 2005:89). ${ }^{6}$

We believe that the stipulation of the Lebanese Court of Cassation for judicial errors, which suggests that it consists of excessive negligence or ignorance, places a clear emphasis upon the fact that a grave judicial error is the error of the judge.

As for the legal jurisprudence and judicial situation in Egypt, we note that the Egyptian Civil and Commercial Procedures Law was devoid of a definition of grave judicial error. Rather it was satisfied merely to provide for it as a reason for the litigation of civilian judges. ${ }^{7}$ Jurisprudence has placed a great deal of importance upon the definitions of this error, and among these definitions is that "the error cannot issue from a judge of ordinary discernment, care and interest in his or her work" (Jira, 1988:98) It is a "wrong for which it is not conceivable that it truly befall someone acting deliberately or recklessly" (Jmi'i, 1976:238).

The jurist Fathi Wali defined that is an "error committed by the judge resulting from the occurrence of a flagrant error which the judge could have prevented if he or she had shown an ordinary level of attention to his or her work, or from excessive neglect in his or her, whether relating to a grave error in the legal principles or the fixed facts of the case in the case file" (Wali, 1993:341). The definition adds that it is an error which is not committed by a judge who is astute and conscientious at his or her work (al-Sharqawi, 1979:54). It is the highest rung on the ladder of error, as it is grave, obscene and extraordinary mistake, and it is inconceivable that it happen to an ordinary judge (Raghib, 2001:228). It is not a normal error, but rather an error which has reached a point of error equal to that of corruption, understood as a deviation from neutrality and a failure to undertake professional duties (Saad, 1975:295).

The Egyptian Court of Appeal defines it in many of its provisions as a professional error to a degree of obscenity, excessive neglect, and suggests that it differs from corruption only in that it takes place in good faith, and it may be an error within legal principles or material facts, and is committed by a judge who does not care about his or her duties, even to a limited degree (Murad, 2002:56). There is no doubt that the Egyptian provisions consider judicial error to be a serious matter arising out of excessive negligence on the part of the judge, and it does not require deliberate action, as this would constitute corruption.

We can observe from the above definitions, which have offered clarification of the meaning of the grave judicial error, that it is described using different terms. However, under close inspection of their content and essence, they are closely related, and are simply tributaries of the same meaning. They describe this error as an unusual

\footnotetext{
${ }^{5}$ Article 741/4 of the Lebanese Code of Civil Procedure No. 90 of 1983.

${ }^{6}$ See also reported from the provisions of the Court of Appeal on the grave judicial error, in the second part of the file, which is allotted to the provisions of the Lebanese Court of Cassation on grave judicial errors.)

${ }^{7}$ Article 494 of the Civil and Commercial Procedures Law No. 13 of 1968.
} 
mistake, the height of wrongdoing, and emphasize that it does not befall the keen, interested, discerning, judicious judge, but rather the ignorant, careless judge who is indifferent to his or her work, and to the importance, seriousness and sanctity of the work of the justice system.

As for in the Hashemite Kingdom of Jordan, the Jordanian legislator left the litigation of civilian judges to the general rules, and did not single out the issue for special rules and provisions as is the case in France, Egypt, Lebanon and other countries which have devoted special laws to the prosecution of civilian judges in its legal system.

Nor did we find any decision of the Jordanian Court of Cassation defining what is meant by gross judicial error, and moreover they did not define grave juridical error generally or specifically. We can grasp some understanding from all of its provisions regarding a serious mistake which apply whether it is a grave error or not, and those relating to work errors. ${ }^{8}$ Doctrinally, it has been defined as: "An error which befalls a judge during the undertaking of his or her work, inadvertently and unintentionally, because of gross negligence in his or her work and a lack of conscientiousness and reflection, or because of his or her ignorance of basic legal principles or the facts established in the lawsuit, which results in damage to one of his or her opponents in the legal proceedings. Or it is an error for which it is reasonably and logically unimaginable that it befalls those who follow the rules of the justice system. It is a mistake which clearly indicates that the judge responsible is not qualified to continue his or her work. It is an exceptionally large mistake, with considerable consequences reaching a grave level; a prolific wrong which exceeds the limits of what is conceivable. It is a result of the absence of legal understanding or concern for legal work, which is an enormous mistake, a clear violation and a disgraceful breach, which is surprising and reprehensible, and an inconceivable occurrence for a judge". 9 It can be noted that his or her definition expresses the essence, substance and content of the grave judicial error, and focuses on the ignorance or negligence of the perpetrating judge, and describes the serious error as the height of wrongdoing. Additionally, the definition is broad and loose. We defined serious judicial errors as a: "wrongful act performed by the judge while undertaking his judicial work resulting in damage to one of the litigants in such a way that would not have happened had the judge been attentive to his or her work, or careful, vigilant and had not neglected his work, or had not had sufficient knowledge of the law he was applying or had not been privy to the facts established in the lawsuit".

We also believe that this error is not "corruption" because he has committed the crime not in bad faith. It is not considered a normal mistake because an obscenity and a violation does not have the range of a usual error. It is a professional judicial mistake because it is linked to the profession of the judge and attached to the judiciary. The reason for attaching the adjective 'grave' to the error goes back to it being a vast, reprehensible and surprising error which befalls a judge who knows the importance and the gravity of his or her work. It is 'grave' also because it is extremely calamitous, of great consequence, and to an obscene level, and the abundance of the extent of the damage is difficult to conceive. It is also 'grave' because it generates a sense of conviction among the injured party, and others, that the perpetrator is either ignorant or careless, which are both qualities which are not conceivable, with reason and logic, and in reality and in truth, qualities for a judge who is trustworthy with regard to the lives, money and honor of litigants.

Finally, it would be preferable if the legislator defined a 'grave error' in general, and in the Civil Code, and if the law of the independence of the judiciary and the Code of Civil Procedure considered a grave judicial error a reason for the litigation of a civilian judge instead of leaving this matter to the general rules. It would also be preferable for the stipulation of grave judicial error, if a definition was provided for it. We also urge the top of the Jordanian judicial pyramid, the highest of judicial authorities, and those which work to establish legal principles at the Court of Appeal, to define for us a serious mistake not only in its rulings considering acting on the perpetration of such grave errors, or not acting, which sets the benchmark of what is a grave judicial error, what is not considered to be so.

\subsection{The Forms of the Grave Judicial Error}

The grave judicial error is characterized in that it emergences in the form of a glaring error in the principles of law, or unjustified negligence in the performance of duty, or a transgression in his or her jurisdiction. It appears in all of these circumstances at the same time, or just in one of them. Accordingly, we will address these forms as

\footnotetext{
${ }^{8}$ From the clause of these provisions: (appeal No. 1236 of the year 51 hearing 3/29/1987, and appeal No. 2333 of the year 51 hearing 18/1/1990, and appeal No. 2467 of year 54 hearing 7/5/1985, and other hundreds of other provisions which are referred to and cited in: Mustafa Magdi Hrjh, Provisions for the Response to the Litigation of Judges and Public Prosecutors, Dar Mahmoud, Cairo, 2009, p147-179.

${ }^{9}$ From the following provisions: Resolution 1309/2004, date 13/10/2004, and Resolution No. 4199/2003, date 04.05.2004, Resolution No. 2504/2005 Date 26/1/2006 justice publications
} 
follows:

\subsubsection{Grave Judicial Errors in the Principles of Law}

A judge is responsible for a grave judicial error if he commits a violation of the law, or an error in the application or interpretation of the law. A violation of the law is: the denial by the judge of an existing legal provision or his or her application of a legal stipulation which does not exist. This case is takes place if the judge neglects to implement a legal stipulation when the legal interpretation of the text is not possible, despite the necessity the case requiring its implementation.

By an error or in the interpretation of the law we mean: that the judge abused correct understanding of a legal stipulation, due to being marred by confusion, ambiguity, obscurity or shortcoming. Consequently, he makes a mistake in his or her the understanding of its meaning and interprets it in a manner which goes beyond the spirit of the law, or wisdom, or what was intended by it.

It goes without saying that what is meant by the law, which is violated or for which an error is made in its application or interpretation, is law in the broad sense that includes the legislative stipulations, regulations and executive directives issued there under, and the provisions of Islamic law, and the principles of Islamic law, and the mores and rules of justice, and the international treaties and conventions which are in force, and the legal rules of a foreign law if the legislature has referred to it (Faouri, 2015:124).

By the principles of the law we mean: the basic rules in the law, the ABCs of law, its axioms and simpler rules. Bearing in mind its characterization according to these features, it is not possible for a judge to make an error with regard to it. If he made a mistake, it should be counted as a grave one because this would mean the ignorance of the judge and his or her lack of knowledge and understanding regarding it, and this is not acceptable from a judge who is entrusted with the lives, protection and money of people, so it makes sense to consider this fault to be grave. A grave judicial error with regard to the principles of law remains a serious mistake as long as occurred in the principles of law, even if it befalls a newly-appointed judge, or one with little experience and know-how, or a judge returning to his or her judicial after a long vacation or a long secondment, or a long suspension, or has return to the work of the judiciary after long years away. It will count as a grave error if the error has occurred in the principles of law, and this is because the standards in this area do not take into consideration the person of the judge, the degree or the length of his or her service, his or her experience and his or her knowledge, or the type and amount of cases awarded to him or her. Rather, it goes back to the extent of ignorance of the judge in the basic principles of law and legal axioms, thus the criteria represent an objective standard, not a personal one.

Accordingly, when a judge commits a serious error, arising from ignorance of the legal principles, which causes harm to the rights of one of the opponents of the case, whether criminal, civil or administrative, legal, religious or regarding customs or tax. In this case the aggrieved is entitled to litigate against the judge for his or her grave error, and to ask him or her for compensation for the material and moral damage caused to him or her.

It should be said that the Court of Merits is what determines and assesses if it was a grave judicial error relating to the principles of the law or not (Faouri, 2015:124). It is worth noting that practical examples of the grave judicial error in the principles of law are many and varied, including:

i. To apply a legal text or canceled the law on the dispute submitted to it. For example, if there is a legal provision which indicates that it is not permissible for the judge that the judge allow a claimant with no evidence for his or her claim to prove it by swearing an oath, and yet the judge proceeds to apply this provision despite it having been annulled for a long period. Or if, for example, the Standards and Metrology Law was abolished, and was replaced by another law which was intrinsically different, yet the judge applied the annulled law on a dispute upon which only the new law can be applied.

ii. The judge requires the defendant to perform a legal oath, although it is not legally permissible for the defendant in the lawsuit to perform a legal oath in the lawsuit.

iii. If the judge issued a ruling in a criminal case which includes the criminal conviction of the defendant for the offense of theft, for example, without their being within the case file any evidence against him or her and without asking him or her about the offense or without allowing him or her to provide testimony, evidence, defenses or arguments despite his or her presence and his or her appearance before the judge.

iv. If the judge undertook to disclose to the media the proceedings and events of a confidential lawsuit, if he was the very person who decided that it should be confidential, and if the case was related to the crime of adultery, incest or rape, and this disclosure resulted in damages to the rights of the victim. 
v. If the judge decided to prevent the travel of a person without the other party having requested this, and without any reason for the request for the issuance of the decision to ban travel.

vi. If the judge decided to remove a suspension of the defendant funds, without the request of the plaintiff or the defendant, without any justification for authorizing it, but removal of the defendant's funds out of annoyance towards the plaintiff or for reasons of revenge and causing harm to him or her.

vii. The judge obliges the defendant or the plaintiff to surrender his or her own rights in favor of his or her opponent i.e. to cease to argue his or her own case.

viii. The judge compels the plaintiff to drop his or her case against the defendant.

ix. The judge issues a decision to arrest the plaintiff in a lawsuit rights without any reason or legal justification.

$\mathrm{x}$. The judge issues a decision in a rights case which includes the imprisonment of the plaintiff even though he is the plaintiff in the case (i.e. not the defendant).

\subsubsection{Gross Judicial Errors in the Performance of Duty}

A grave judicial error in the performance of judicial duty is considered an invariable form of grave judicial error. By a grave judicial mistake in the performance duty the following is meant: the unjustified, unacceptable and excessive negligence of the judge in the discharge of his or her judicial work (al-Mahayni, 2000:244). Some call it the following: acute or abnormal negligence, because it is the most extreme level of negligence for the judge. It could not befall a judge with an ordinary level of concern for his or her work, but rather only a judge who is removed from his or her work dramatically and significantly (Faouri, 2015:139).

We believe that in the event of such a mistake befalling a judge, that we should consider that it has befallen a person for which it is not conceivable with reason and logic that it befall him or her. We should, in these circumstances, disregard the age of the judge or his or her legal level or experience, or physical and mental health and social situation, or the amount and type of cases he has undertaken, because this standard is objective, not personal. A person who has ascended to justice bench should be aware of what it represents, and the concern, efforts and diligence it requires from him or her in the cases entrusted to him or her. He should be aware, too, that his or her work is not just to preserve the people's rights, freedoms and interests, but beyond that to include their lives and the safety of their bodies, honor, minds and wealth and so on.

We believe that the judge will have perpetrated a grave mistake because of his or her neglect of duty, as it befalls him or her when he is enjoying the title of judge, and during the exercise of his or her judicial work. It is gross negligence which is not simple or ordinary, and is devoid of ill will, deliberate intention or corruption, and it generates physically or mentally harm to one of the litigants in the case entrusted to him or her. It should be noted that the practical examples of grave judicial error in the form of the performance of duty are many, for example the following:

A. The judge issues a ruling in the case, without this provision being printed, written, or in a draft, and the period of appeal expires without the ruling being printed or written or in draft form, which prevents the conviction and the issuing of the sentence and denies his or her right of appeal.

B. If the judge decided to release the defendant with the bail which has been provided to him or her and approved, but did not issue the written release and send it to the detention center.

C. If the duration of the arrest of the defendant ended without him or her being released or his or her detention being extended.

D. If he decides to prevent the travel of the defendant, and then fails or neglects to send a written declaration of the decision to prevent travel directly to the relevant authorities, which in turn enables the defendant to travel and causes damages to the plaintiff.

E. The judge diverts attention from the hearing witnesses, which is a general right in a criminal case, without justification or legal reason. Or he prevents their attendance to testify, or refuses to listen to their testimony, and then declares the defendant guilty because of their non-attendance, so if these witnesses had been heard then the judgement would have been different, and so the plaintiff has been harmed in this matter.

We believe that the error of the judge in the following situations does not constitute such a serious judicial error in the performance of duty: failure to adapt the case, or in the estimation of the value of cases, or his or her absentmindedness from rendering judgement for motions or requests, or the occurrence of material or mathematical mistakes, or the lack of a proper explanation for a ruling, or an error in the weighing up of the evidence, or the failure to sign the judgment or its draft. These are not serious judicial errors, due to the absence 
of excessive or acute negligence them and it is not considered unjustifiable neglect in his or her work.

\subsubsection{Grave Judicial Errors in the Carrying out of Jurisdiction}

The last form of the grave judicial error is the grave judicial error in terms of jurisdiction, by which is meant that there is a transgression in the jurisdiction of the judge responsible for the case. That is, he undertakes the overseeing of particular a case and the issuing of a judgment without being legally competent, whether in terms of it not being his or her expertise or his or her kind of work or it not being his or her particular place of work, and he is aware of this fact, because knowledge is assumed as he or she is a judge. Worst of all, if he recognizes that this is not his or her specialty and yet he or she continues to work (Faouri, 2015: 154).

Among the examples of gross judicial error in the form of a transgression in jurisdiction are the following:

A. The issuing by a civil judge of a judgment which includes the judgment of the divorce of a wife from her husband.

B. The issuing by a shar'ia judge of a judgement on the eviction of renters.

C. The issuing by a military judge of a ruling that includes the dissolution of a lease.

D. The issuing by the judge of a magistrate Court of a ruling in a murder, rape, indecent assault, kidnapping or other cases which enters the jurisdiction of the Central Criminal Court.

E. The issuing by a general prosecutor of prison sentence instead of an arrest in a case of corruption.

F. The issuing by a civil executive judge, and not a shari'a one, of a ruling of the custody of children to their father.

G. The issuing by a civil case management judge of a ruling compelling the defendant to pay damages.

H. The issuing by an intermediary judge to terminate an employment contract.

It is worth mentioning that the examples of the grave judicial error in the domain of a transgression of jurisdiction are innumerable. In the examples mentioned, the civil judge must take responsibility for these mistakes, and it is the right of the aggrieved to litigate against the judge and demand compensation from the judge for damage caused to him or her because of it. It is not possible for the judge to distance himself or herself from responsibility due to his or her recent appointment, or that because the case is thorny or hard to compare to any similar case, or that his or her workload forced him or her into committing this error, or that he thought that the law had been changed or modified, or that a psychological condition affected him or her at the moment of the issuing of judgment, or that the President of the Court or any other judicial officer, asked him or her , using either threats or bribes, to issue such a decision. This defense, or any denial of responsibility will not be accepted from him or her because he is a judge, and it is inconceivable from him or her that succumb to intimidation or cajoling, or to fall into such errors, as they are connected to the basic principles of law, which are considered the simplest rules of law, its $\mathrm{ABCs}$, axioms, postulates and priorities for which it is logically and reasonably impossible to imagine their occurrence to an individual who sits on the bench of jurisdiction. This standard is objective, not personal.

Thus, we see from the above the forms of grave judicial error for a judge, which has been left by the legislature without any stipulation despite its importance. It would be better if the legislature dealt with this shortage and these inadequacies and provides for it in the Civil Code, the Code of Civil Procedure and the law of the independence of the judiciary, bearing in mind its importance and gravity.

\section{Applications of the Grave Judicial Error, Its Reasons for Occurring and Ways to Avoid It}

This section includes three issues worthy of attention. The first is the judicial applications for the grave judicial error in order to define what is considered a grave judicial error and what is not. This will help us to achieve an integrated understanding of the gross judicial error from the two sides of scientific theory and applied practice. The second issue deals with the definition of the reasons for the occurrence of grave judicial error, which helps in turn to present solutions for the prevention of this error, and hence the importance of the third issue. It is of no use knowing the reason or reasons for the error without offering solutions.

Based on the above, we will divide this section into the three issues, and we will devote a separate section to each issue them, as follows:

\subsection{Applications of the Gross Judicial Error.}

The court rulings issued by the Jordanian Court of Cassation are devoid from any provision concerning grave judicial errors from a rights perspective. Not only that, but the rulings from the court regarding the general 
applications of the grave judicial error are very few, and are all related to work injuries in labor law and social security law, or to the misuse of a constitutional legislator license by citizens with recourse to the judiciary, or the obtaining by a carrier of a false check, or the mistakes of the administrative governor, the directors of the police or the leader of the military. ${ }^{10}$ The Court of Cassation stated whether these rulings should be considered as having committed grave judicial errors or not. The reason for the lack of judicial applications for the grave judicial error in the provisions of the Court of Cassation is not because the kingdom's court judges, whether in regular or special courts, are infallible and incapable of committing a serious mistake, and such mistakes do not befall them, and it is not because of the inadmissibility of their litigation, which it is permissible in accordance with the general rules which do not preclude or deviate from their litigation him or her in the light of the general rules, but rather it is due to the following:

A. The great desire of the opposition and their agents not to enter into civil suits for making accountable and litigating judges for their mistakes, gross or otherwise, and with whether forced to or out of fear, or wishing to reduce time and expenses, and their desire in the ways of the realms of the President of the Judicial Council, or the head of the Judicial Inspection Unit, or the President of the Court of Appeal, or because of the launch of an appeal against the gross error perpetrated by the judge, or the presentation of a call back request by the judge.

B. The satisfaction or convinced of the opponents or their agents of the virtue of court of first instance and decision not to appeal and the response to the raising of a suit against the judge for his or her gross error being that there is a lack of evidence.

C. The premature lapse of the lawsuit against the civilian judge, before the Court of First Instance, that is without any judgement being made on the matter, so as to bring down these suits temporarily, or to cause their complete collapse, not due to their fulfilment, but rather due to a lack of desire to continue with the lawsuit.

As for in France, the applications of the serious judicial error are many and wide-ranging (al-Barakat, 2001: 152)

A. The negligence of a judge to undertake in general the measures that are stipulated by law is the cause of the invalidity of expert work and the subsequent procedures, and causes serious harm to the litigants.

B. The poor selection of the expert, and the lack of monitoring of his or her activity by the judge.

C. All defects or deficiencies in the work of justice which befalls the judge responsible for a case.

D. Any action which indicates the inability of the judge to do his or her job.

E. The delay in delivery of copies of the judgment to the litigants for a period in excess of a year.

F. Disclosure of information from confidential session.

On the other hand, the following are not considered such a serious judicial error in France (al-Barakat, 2001: 151):

A. Any error which can be remedied by means of an appeal.

B. Any words or descriptions expressed by the judge related to recounting the facts of the case or its judgement.

C. The judge's ruling is the result of hurtful phrases or libellous accusations.

D. Lack of proper adjustment of the legal action, or lack of particular attention to the particular facts, and the treatment of information, its weighing up and assessment.

E. The renewal of the procedures of closing the bar as long as the owner is still working as a pimp.

F. Imprisonment of one of the defendants for breach of the sanctity of the court system.

We note from the above, that in the French judiciary, it is only considered a serious error when he has reached a particular degree of obscenity, which really hurt one of the opponents, and the opponent was not able to address or remedy this error my means of appeal.

Regarding the applications of the grave judicial error in Lebanon, they are many of them (Saab, 2005:89)

A. The plaintiff is awarded an amount greater than that which he demanded in the lawsuit.

B. Negligence of the judge to settle the case under oath, despite the passing of judgement in the lawsuit.

C. The ruling that a person must pay an amount of compensation without a lawsuit, request or demand of

\footnotetext{
${ }^{10}$ The rulings that have been published on the website 'Legal Justice in Jordanian Laws and Judicial Decisions numbered a total of 36 judgment only, as of 01/05/2016.
} 
compensation from him or her.

D. The application of a law that has long been annulled and is not relevant to the dispute.

E. Application of a legal provision onto an incident that it does not apply to.

F. The incorrect interpretation of a legal stipulation.

G. Ignorance of the law by the judge.

H. The excessive and gross negligence of the judge in the performance of his or her work.

I. The passing of a judgment without studying the case file.

J. The failure to inquire about the necessary law to be applied.

$\mathrm{K}$. The judge becoming negligent and making a blatant mistake during the proceedings.

We can note from these applications that they associate a grave judicial error with the existence of a flagrant mistake and an extraordinary negligence in the performance of duties, and they give this error of a personal nature, meaning that they associate the judge with the source of the ruling or the undertaking of the procedure. In contrast, in Lebanon the following are not considered gross judicial errors:

A. Not violating legal rules, an expansion of the interpretation of legal rules, or not going contrary to the intent of the legislation.

B. If the decision is a fully reasoned explanation which distances the judge from accusations of clear professional negligence or ignorance.

C. The absence of excessive negligence or ignorance of the judge as the source of the decision.

D. Ending up with a result in which the judge does not recognize the rest of his or her colleagues or jurisprudence.

E. The commitment by the judge of a material or calculating error, when writing the decision.

The reason for the lack of a serious error in these cases is that the judge did not commit a flagrant wrong or enjoy an ignorance of the law applied in the law, and he did not neglect the performance of his or her duty.

Applications of grave judicial error in Egypt are as follows:

A. Negligence to the highest degree or in the most extreme imaginable form.

B. An obscene error whose gravity is close to that of corruption, but on the condition of not being in bad faith.

C. Inexcusable ignorance of the judge regarding the fixed the facts in the case file.

D. The mistake of the judge should not be simple or ordinary.

E. The error is not related to the certification of the facts.

F. That the error is not related to the legal adaptation of the suit.

G. Excessive negligence of the judge.

H. The fault is not due to a violation of the views Fiqh or jurisprudence.

It can be noted from the above applications that the judiciary of the Egyptian Court of Appeal embrace the narrow concept of the gross judicial error. On the other hand, the following is not considered a grave judicial error in Egypt (Hrjh, 2009:291):

A. Any legal opinion or application concluded by the judge after careful consideration and diligence in developing legal solutions for the issue at hand even if it goes against other court rulings or jurisprudence.

B. If the error is not inconceivable and does not indicate clear neglect in the performance of duty.

C. If it pertains to the adaptation of laws or the weighing-up of evidence.

D. If combined with an ordinary level of negligence.

E. If it does not indicate the ignorance by the judge of the legal principles or the facts established in the case file.

It is noted again that the Egyptian Court of Appeal adopts a narrow concept of judicial error particle, meaning many of the judicial errors do not fall under the guise of a serious mistake. It is considered a grave judicial error when it relates to excessive neglect or ignorance of the law. The error may have reached the highest extremes of inconceivability. 


\subsection{Reasons for the Occurrence of a Serious Judicial Error}

The reasons for the occurrence of a serious judicial error include the following (Faouri, 2015:315):

A. The low legal level of the judge, his or her ill-fittedness for the post of the judiciary, and for sitting on the judicial bench.

B. Indifference of the judge to the importance and seriousness of his or her work.

C. Negligence, inaction, carelessness and tardiness in the performance of his or her work.

D. Little or no practical experience.

E. Failure to keep up with a series of new legal amendments and judicial interpretations.

F. Not referring to the provisions of the law and the explanations of jurists.

G. The large number of cases assigned to him or her.

H. The convergence of many suits with complex and difficult and difficult aspects.

I. The confusion of the judge

J. Hearing a case while in a state of anger, fatigue or illness.

$\mathrm{K}$. Judge failing to provide new, revised laws and up-to-date judicial decisions.

We also note that there are a number of other reasons, including:

A. The failure of judge to undertake a long enough period of fruitful and successful training before being consigned to sit on the bench.

B. The assignment of a newly appointed judge to difficult, ground-breaking cases relating to controversial issues.

C. The judge is embarrassed by a question asked of him or her by his or her colleague or the head of his or her court about a point or a legal issue.

D. A judge attempts to pass judgement on the largest possible number of cases for the purposes of his or her monthly and annual report.

E. The failure to provide comfort and security to the judge.

F. The prevention of the judge from reading jurisprudential legal books.

G. The assigning of a judge onto lawsuits which exceed the quantity and quality for his or her ability.

H. The frequent amendments of laws, and the lack of stability in many of the provisions of the Court of Cassation.

I. Lack of consideration in the passing of a judgment

J. Attempting excellence and innovation by issuing provisions are not based on a sound legal basis or support.

\subsection{Means for Avoiding Gross Judicial Errors}

You can avoid serious judicial error, or reduce its incidence through the following (Faouri, 2015:327):

A. Working on increasing the number of judges

B. The existence of parity in the distribution of cases among judges, as it is not fair that judge be entrusted with a thousand and his or her colleague with just one hundred.

C. Finding a system of specialization in relations to cases, as judges finds it difficult to oversee civil, commercial, penal and labor cases at the same time.

D. The most experienced and knowledgeable judges should be assigned into thorny cases which involve significant aspects of complexity.

E. Ensure strictness and firmness in the abilities of a judge before appointment.

F. To provide all means of comfort to the judge.

G. Dispatch judges on intellectual and practical research, internally and externally.

H. Arranging a program of the continuous training of judges.

I. Providing a legal researcher for each judge, in addition to the follow-up clerk, with an independent character meaning they shall not participate in their work with colleagues. 
J. New laws, and new and amended provisions of the Court of Cassation should be provided to judges.

We note in addition to the above, the following:

A. Activating the role of the force for the inspection of the judiciary.

B. Activating the role of the chief judge.

C. Subjecting judges to monthly and annual assessment.

D. Disciplinary sanctions against judges who repeatedly commit serious errors.

E. Reducing the large number of unexplained transfers and judicial formations.

F. Monitoring the number and kind of cases assigned to a judge.

\section{Conclusion}

This study addressed the subject of serious judicial errors, and produced a number of findings and recommendations, as follows:

First, findings:

The gross judicial error is not idea of recent genesis or foundation, but rather it is a very old idea rooted in hundreds of years in France. However, the Jordanian legislative system continues not to contain any stipulation for it, without logical justification or mental rationalization, or practical reality.

Jordanian legislation has left the litigation of civilian judges to the general rules, without singling it out for special rules and provisions as is the case in France, Egypt, Lebanon and other countries which have devoted specific legal systems to the litigation of civil judges. Nor did we find any provision from the Jordanian Court of Cassation defining what is meant by grave judicial errors.

We define serious judicial errors as being: "a wrongful act committed by the judge during his or her undertaking of judicial work which results in damage to one of the litigants in the case, in such a way that the damage would not have taken place had the judge been attentive to his or her work, or careful, vigilant and not negligent, or had had knowledge of the law applicable to the case or had been privy to the facts established in the lawsuit."

Among the forms of gross judicial error: gross judicial error in the principles of law, gross judicial error in the performance of duty and gross judicial error in jurisdiction.

The applications of grave judicial error in Egypt, France, Lebanon differ from each other. In France, there is an objective standard, and in Egypt an at once personal and objective standard, and in Lebanon a personal standard. In Jordan, it is up to the general rules, and we have not found decisions by the Court of Cassation of Jordan on this matter.

The reasons for the occurrence of the serious error are many, different and varied and there are ways to avoid them.

Secondly, recommendations:

We urge the Jordanian legislator to regulate the civil litigation of judges in Civil Procedure Law and Civil Law, and to provide for it in the Law of the Independence of the Judiciary.

We urge the Jordanian legislator to define serious judicial errors in general and in particular, and we urge the same of the Jordanian Court of Cassation.

We call for work to avoid the causes of the occurrence of serious judicial mistakes through: Work to increase the number of judges and the presence of parity in the distribution of cases among judges, because it is not fair that one judge be entrusted with a thousand cases and his or her colleague just a hundred cases. Also, work to find a specialization system with regard to cases, as a judge may find it difficult to work on civil, commercial, criminal and labor cases at once. Additionally, that the most experienced judges be entrusted with the thorny cases which involve significant complex aspects. To ensure the strict and firm ability of the judge before appointment. The provision of all means of comfort to the judge. The dispatch of the judges, both internally and externally, for the purpose of educational missions. The creation of a continuous training program for judges. The provision of a legal researcher for each judge, in addition to follow-up clerk, and their independent character shall mean that they do not participate in work with colleagues. The judges should be provided with the new laws, and the new and amended provisions of the Court of Cassation. The role of judicial inspection service should be stimulated, as should the role of the chief judge. Judges should be subjected to a monthly and annual assessment. Disciplinary sanctions should be placed on the judge who repeatedly commits serious errors. The frequency of transfers and unexplained judicial formations should be reduced. Finally, the amount and type of cases assigned 
to the judge should be considered.

Provision for the forms of the grave judicial error (in the principles of law; in jurisdiction; in the performance of duty).

Provision for the forms of grave judicial error in the principles of law and jurisdiction in the performance of duty.

\section{References}

Al-Faoury, A. M. (2007). Lodging a Claim Against a Judge. Amman, Jordan: Dar al-Thaqafa.

Al-Khoury, Y. (2002). General Administrative Law (Part Two). Beirut, Lebanon: Dar Sader.

Al-Mahayni, M. (2000). Litigating Judges and Representatives of the Public Prosecution. Damascus, Syria: Al-Nouri Institution.

Al-Minshawi, A. H. (2008). Commenting on Procedural Law in Civil, Commercial and Administrative Materials. Alexandria, Egypt: Dar El Matboaat El Gameya.

Al-Qisas, M. E. (2005). The Mediator in Civil, Commercial and Administrative Law Proceedings. Amman, Jordan: Dar al Nahda al Arabeya.

Al-Sharqawi, A. M. (1979). Explanation of Procedure Code.

Al-Znon, H. A. (2005). Al-Mabsoot in Civil Liability (Part One). Amman, Jordan: Dar Wael.

Al-Zoubi, A. A. (2003). Civil Procedure. Amman, Jordan: Dar al-Thaqafa.

Barakat, A. (2001). Litigating Judges: Between Theory and Practice. Cairo, Egypt: Dar Al Nahda Al Arabeya.

Hindi, A. (2002). Law of Procedure Ordinance. Alexandria, Egypt: Monchaat Al Maaref.

Hrjh, M. M. (2009). The Provisions for the Response to and Litigation of Judges and Members of the Public Prosecution. Cairo, Egypt: Dar Mahmoud.

Jira, A. M. (1998). Justice System in Saudi Arabia: A Comparative Study. Riyadh, Saudi Arabia: Institute of Public Administration Publications.

Jmiei, A. B. (1976). Jurisdiction Theory. Cairo, Egypt: Dar El Fikr El Arabi.

Jordanian Civil Law No. 43 of 1976.

Law of the Jordanian Judiciary Independence No. 29 for the year 2014.

Laws and Judicial Rulings:

Meligi, A. (2002). The Comprehensive Encyclopedia in the Commentary to the Code of Procedure (Vol VI). Technical Office of Legal Releases.

Murad, Y. (2002). Response and Litigation with Members of the Judiciary (1st ed.). Cairo, Egypt: Dar Al Nahda Al Arabeya.

Ragheb, W. (2001). The Principles of Civil Justice. Cairo, Egypt: Dar Al Nahda Al Arabeya.

Rushdie, M. S. (1995). Inexcusable Mistake. Kuwait: Kuwait University Printing House.

Saab, M. M. (2005). Litigating Judges. Beirut, Lebanon: Al-Halabi Legal Publications.

Saad, I. N. (1975). Judicial Code (Part One). Alexandria, Egypt: Monchaat Al Maaref.

Sawi, A. A. (1990). The Mediator in Civil and Commercial Procedural Code. Cairo, Egypt: Cairo University and University Book Printing House.

The Civil Procedure and the Egyptian Trade Code No. 13 for the year 1962.

The Jordanian Civil Procedure Law, as amended, No. 24 of 1988.

The Jordanian Court of Cassation decisions.

The Lebanese Civil Procedure Code No. 90 of 1983.

Wali, F. (1993). Mediator in the Civil Justice Law. Cairo, Egypt: Dar Al Nahda Al Arabeya.

Yazbek, M. A. (2009). The Great Judicial Mistake: A Comparative Study Between Lebanon and France. Beirut, Lebanon: Dar al-Jeel. 


\section{Copyrights}

Copyright for this article is retained by the author(s), with first publication rights granted to the journal.

This is an open-access article distributed under the terms and conditions of the Creative Commons Attribution license (http://creativecommons.org/licenses/by/4.0/). 